patrystyozna, Koścí́ a państwo, asoetyzm, 11turgia. Oczywiscie trudno było- przy tak posunietej dzis specjalizacji badań naukoryoh, dobrá problemy jednorodne. Bezpośrednio szło sie na któryó z trzech wykładów. Zakońozenie i tak przeładowanych dni stanowiz odczyt /od godz. 20.30/ o tematyce ogólniejszej np. Aktualnosol Orygenesa; Poglądy Augustyna na temat stworzenia, czasu 1 चiecznośc1; Przykład platońskiego ohrześc1jaństwa; Proudo Dionizy Areopagita, Jego poprzednioy 1 nastepcy.

Oczywífole nie wazyscy uozestnioy mogli 1 oholeli szuchac wszystkioh odczytów 1 komunikató nawet jodnoj sokcji. Piekny, pezen uroku średniowlecznej 1 renesansomej architektury 0ksford twarzal pokuse, 1 to silna, do "urywania się" z zajęc kongresowych; podobnio dzlałały nęcace kglęgarnie, znane dobrze specjallstom. Przygotowaly one cale swe zasoby z daledziny antyku chrzéscijaríkiego.

+ Lookadia Małunowioz6rna

2. BENEDYKTYASKIE SYMPOZJUM PATRYSTYCZNE

W dniach 22-23 września 1980 roku w Metropolitalnym Seminarium Duchownym we Troclawiu odbyło s1ę Ogólopolskie Sympozjum Patrystyczne, zorganizowane przez Sekcje Patrystyczna przy Komisj1 Nauk Episkopatu Polski, poświęcone tym razem osoble 1 Regule św. Bonedykta Opata z okazji 1500-1ecta jego urodzin. Pod nleobecność gospodarza, Ks. Arcybiskupa H. Gulbinowioza przebywajacego warszewie, sympozjum otworzy $\mathrm{Ks}$. Bp 罚. Urban wraz z prezesam Sokoji Patrystyczned Ks. Dram St. Longoszem. slowie wstepnym prezes sekoji uzasadniz tytul 
"Benedykt Patronem Europy", przedstawil ostatnie wypowiedz1 papieskie o jego zasługach oraz umiécil rozpoczynajace sie sympozjum w kontekście światowych jubileuszowych sympozjów 1 obchodów benedyktyńskich.

W plerwszej prelekcji Ks. Bp W. Urban przedstawil szeroko tło historyczne Europy, na którym pojawiła sie postać wielkiego organizatora zyola zakonnego 1 społecznego. Nastepnie Ks. Dr M. Starowieyski scharakteryzował Regułe św. Benedykta na tle starozytnych reguz zakonnych, ukazujac jej oryginalnośd 1 zalezności. Po południu wystapili duchori spadkobiercy áw. Benedykta, 0. Dr P. Szczanieoki OSB z Tyrica oraz Siostra Mgr M. Borkowska OSB z Zarnowca. P1erwszy scharakteryzowaz bogata duohowość ́́w. Benedykta, druga zaś omómiła wpływ 0joóm Pustyni na treśc Reguły wielkiego zakonodawoy. Sesje wieczorna pó́tieoono problemom nauczania patrologii w seminariach duchownych. Sprawozdania z poszczególnych ośrodków ujawniały niekiedy kompletny brak zainteresowania ta wazna, następująca zaraz po Písmie ów. dyscypliną wiektórych seminariach duchownych, brak podstawowych, nawet polskich, ksieggozbiorów patrystycznych, brak kwalifikacj1 wielu wykładowców.

Następny dzień sympozjum rozpoczęto uroczysta liturgia eucharyatyczna poświęconq św. Benedyktowi, koncelebrowanq przez uczestników pod przewodnictwem Ks. Bpa W. Urbana, który w homili1 mocno podkreślił znaczenie ojcóm Kościoła dla pełnego 1 zdrowego rozwoju teologil. W sesji przedpołudniowej wystapila najpierw Pani Prof. A. Swiderkówna, która przedstawiła swe uwagi zebrane podczas przygotonywania nowego polskiego tłumaczenia Reguły św. Benedykta 1 poświęconej mu II księg1 Dialogón áw. Grzegorza Wielkiego, wydanych pod koniec ubiegłego roku przez 0jców Benedyktynów w Tý́cu. Następnie 0. Dr A. Bober SJ scharakteryzował pierwsze piśmiennictwo synów św. Benodykta. 
Obok prelekoj1 wygłoszono k11ka komunikat6w: Mgr B. Wronikowska objaśniła najstarszy wizerunek sw. Benedykta watakumbach św. Hermesa w Rymie, ojcowle benedyktyni omówili wrocławskie tradycje benedyktyńskie oraz kult áw. Benedykta w Polsce, przedstawiciele prawosławia - kult św. Benedykta w Kościele Wschodnim.

Chociaz wrockawskie sympozjum patrystyczno by $¥ 0$ niewatpliwie najwlekszym naukowym wydarzeniem zorganizowanym w ramach jubileuszowych obchodó benedyktyńskich Polsce, to pralekcjach wyczuwało sie brak podkré́lenia zasług b́. Benedykta 1 jego synów zarówno wobec kultury europejskiej, jak 1 wobec chrystianizacji Polski.

Na zakończenie uczestnicy /w sumie ok. 60 osób/, wśród których byl1 00. Benedyktyn1, przedstawiciele Kośc1oła Prawosłamnego, przedstawiciele KUL-u 1 ATK, Uniwersytetu Jaglellońsklego, Warszawskiego 1 Wrocławskiego oraz niemal wazystkich seminariów duchownych w Polsce/wóród nich po raz piermszy delegaci-klerycy z seminariów: kieleckiego, katowickiego, lubelskiego, gorzowskiego, warszawskiego, wrocławskiego, włockawskiego i tuchowskiego 00. Redemptorystón/ przesłali telegram na rece 0jca Swietego Jana Pawa II, wielkiego protektora wszelkich poczynań patrystycznych.

H. Wolak 
T E L E G R A M

uczestnikóm ogólnopolskiego Sympozjum Patrystycznego we Wrocławiu do 0jca Swietego Jana Pawła II

\author{
Jego Swiątobliwość \\ J A N P A W E L I I \\ Città del Vaticano \\ R 0 M A
}

Uczestnicy Sympozjum Patrystycznego pośmięconego osobie 1 Regule świętego Benedykta Opata, zebrani we Wrocławiu, przesyłaja $\mathbb{F a z e j}$ Swiątobliwości wraz $z$ moditwami wyrazy holdu, uczuoia radośc1 1 oddania, prosząc o błogosławieństwo dla dalszych prac Sekcj1 Patrystycznej.

\author{
X. Wincenty Urban \\ biskup sufragan wrocłamski \\ ks. Stanisław Longosz \\ prezes Sekcji Patrystycznej \\ Barbara Filarska KUL \\ 0. Tmil Stanula CSsR ATK
}

Warszama, 22. IX. 1980. 


\section{SECRETARIA STATUS}

Froselencjo,

W Imientu Jego Swiatobliwó́cl Jana Pawła II przesyłam na rece Waszej Ekscelencji, eerdecsno podziekowanie dla Uczestnikbw Sympozjum Patrystycznego we Wrocławiu, pośmięconego Ogobie 1 Regule św. Benedykta.

ojciec Swiety z całego geroa udziela Waszej Ekscelencji, a takze uczestnikom Sympozjum Apostolskiego Błogosławieństwa na dalsze prace dla dobra Kościoła.
Laczę wyrazy szacunku

$$
\begin{array}{r}
\text { - Podpis: + E. Martinez } \\
\text { Substytut }
\end{array}
$$

Jego Ekscelencja

Najprzewielebniejszy

Ks. Biskup Wincenty URBAN

ul. Kanonia 12

50-328 Wroc zaw

Polonia 